University of Nebraska - Lincoln

DigitalCommons@University of Nebraska - Lincoln

$1-1-2008$

\title{
Influence of heterocyclic and oxime-containing farnesol analogs on quorum sensing and pathogenicity in Candida albicans
}

\author{
Roman Shchepin \\ University of Nebraska - Lincoln \\ Dhammika H.M.L.P. Navarathna \\ University of Nebraska - Lincoln \\ Raluca Dumitru \\ University of Nebraska - Lincoln \\ Shane Lippold \\ University of Nebraska - Lincoln \\ Kenneth W. Nickerson \\ University of Nebraska-Lincoln, knickerson1@unl.edu \\ See next page for additional authors
}

Follow this and additional works at: https://digitalcommons.unl.edu/chemistrydussault

Part of the Chemistry Commons

Shchepin, Roman; Navarathna, Dhammika H.M.L.P.; Dumitru, Raluca; Lippold, Shane; Nickerson, Kenneth W.; and Dussault, Patrick, "Influence of heterocyclic and oxime-containing farnesol analogs on quorum sensing and pathogenicity in Candida albicans" (2008). Patrick Dussault Publications. 6.

https://digitalcommons.unl.edu/chemistrydussault/6

This Article is brought to you for free and open access by the Published Research - Department of Chemistry at DigitalCommons@University of Nebraska - Lincoln. It has been accepted for inclusion in Patrick Dussault Publications by an authorized administrator of DigitalCommons@University of Nebraska - Lincoln. 


\section{Authors}

Roman Shchepin, Dhammika H.M.L.P. Navarathna, Raluca Dumitru, Shane Lippold, Kenneth W. Nickerson, and Patrick Dussault 


\title{
Influence of heterocyclic and oxime-containing farnesol analogs on quorum sensing and pathogenicity in Candida albicans
}

\author{
Roman Shchepin ${ }^{\mathrm{a}}$, Dhammika H.M.L.P. Navarathna ${ }^{\mathrm{b}}$, Raluca Dumitru ${ }^{\mathrm{b}}$, \\ Shane Lippold ${ }^{\mathrm{b}}$, Kenneth W. Nickerson ${ }^{\mathrm{b}}$, and Patrick H. Dussault ${ }^{\mathrm{a}, *}$ \\ ${ }^{a}$ Department of Chemistry, University of Nebraska-Lincoln, Lincoln, NE 68588, USA \\ ${ }^{b}$ School of Biological Sciences, University of Nebraska-Lincoln, Lincoln, NE 68588, USA \\ * Corresponding author
}

\begin{abstract}
A series of synthetic molecules combining a geranyl backbone with a heterocyclic or oxime head group are quorum-sensing molecules that block the yeast to mycelium transition in the dimorphic fungus Candida albicans. A number of the analogs have an $\mathrm{IC}_{50} \leq 10 \mu \mathrm{M}$, a level of potency essentially identical to the natural quorum sensing signal, the sesquiterpene farnesol. Two of the most potent analogs, neither toxic toward healthy mice, display remarkably different effects when co-administered with $C$. albicans. While neither offers protection from candidiasis, one analog mimics farnesol in acting as a virulence factor, whereas the other has no effect. The results offer the first example of highly potent synthetic fungal quorum-sensing molecules, and provide the first evidence for the ability to decouple quorum sensing and virulence.
\end{abstract}

\section{Graphical abstract}

A series of farnesol analogs are potent quorum-sensing molecules for the human pathogen Candida albicans. Two of the most potent analogs display very different effects in a mammalian model of systemic candidiasis.

Keywords: Farnesol, Quorum sensing, Candida albicans, Virulence, Candidiasis, Oxime, Tetrazole, Triazole, Thiotetrazole, Thiotriazole, Thioimidazole

\section{Introduction}

Candida albicans normally resides as a harmless yeast in the GI and urinary tracts, and to a lesser extent on the skin, of most humans. However, for patients with weakened immune systems (e.g., AIDS patients, transplant recipients, and premature infants) C. albicans is an opportunistic and often deadly pathogen that will invade host tissues, undergo a dimorphic shift, and then grow as a fungal mass in the kidney, heart, or brain. Candida albicans is the fourth leading cause of hospital-acquired infection in the United States and over 95\% of AIDS patients will suffer from infections by $C$. albicans. ${ }^{[1]}$ and ${ }^{2]}$ There is a pressing need for new treatments for fungal infections.

Candida albicans is a polymorphic fungus able to grow as yeasts, hyphae, and pseudohyphae, and a great many chemical and environmental factors influence the relative populations of these morphologies. In liquid culture, C. albicans develops as either yeasts or hyphae, depending in part on whether the cell densities are above or below $10^{6}$ cells per $\mathrm{ml} .^{3}$ Our research revealed that the population dependence of $C$. albicans morphology results from the continuous production and detection of the sesquiterpene farnesol (1, Table 1), ${ }^{[3]}$ and ${ }^{[4]}$ which acts to block the yeast to mycelium transition at concentrations as low as $1-2 \mu \mathrm{M}^{[5]}$ and ${ }^{[6]}$ In accordance with the precedent established for homoserine lactones in Gram-negative bacteria, ${ }^{7}$ the phenomenon was termed quorum sensing. Farnesol was the first quorum-sensing molecule (QSM) to be discovered in an eukaryotic system. ${ }^{[3]}$ and [4]

The dimorphic nature of $C$. albicans is essential for pathogenicity. ${ }^{8}$ The discovery of a QSM able to direct growth in the yeast phase therefore suggested the possibility of a "single morphology therapy" which would force this opportunistic pathogen to remain in a monomorphic, nonpathogenic lifestyle. However, three separate experiments have shown that farnesol actually increases fungal pathogenicity. First, cultures of $C$. albicans pretreated with subinhibitory doses of fluconazole, a protocol that increases the levels of secreted farnesol 8 - to 10 -fold, ${ }^{9}$ were 4 - to 5 -fold more pathogenic to mice. ${ }^{10}$ Second, mice which received farnesol either in their drinking water or via intraperitoneal injection showed ca. 4-fold higher lethality from candidiasis than mice receiving control IP injections. ${ }^{11}$ Third, a knockout mutant of C. albicans lacking the 
Table 1. QSM activity of oximes

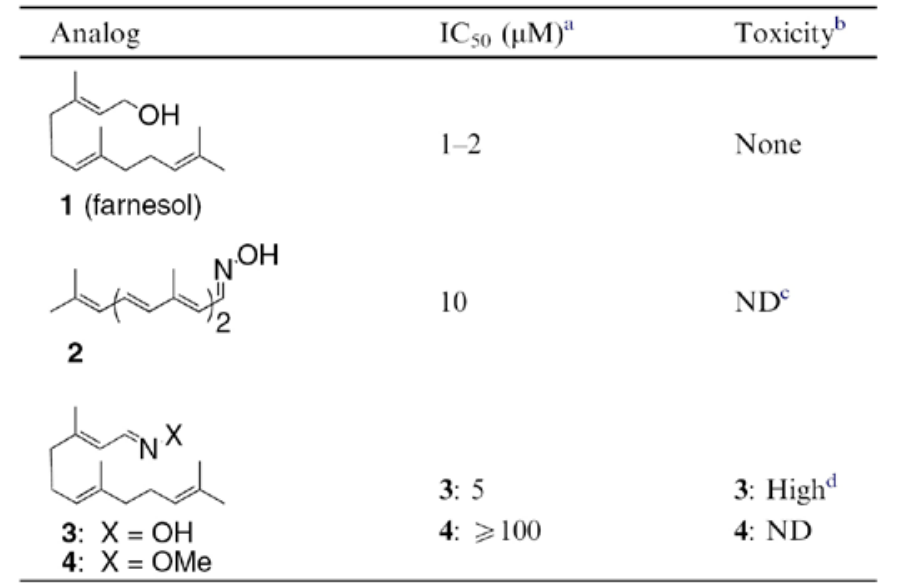

${ }^{\mathrm{a}}$ Inhibition of germ tube formation.

${ }^{\mathrm{b}}$ Healthy mice observed over $14 \mathrm{~d}$ following injection (IP) with $1 \mathrm{ml}$ of 20

$\mathrm{mM}$ solution $(0.5 \%$ Tween $80 \mathrm{v} / \mathrm{v}$ in sterile, nonpyrogenic saline).

${ }^{\mathrm{c}}$ Not determined.

${ }^{\mathrm{d}}$ Mice died within $4-5$ days.

$D P P 3$ gene encoding an isoprenoid pyrophosphatase for conversion of farnesyl pyrophosphate to farnesol, and thus producing only $15 \%$ as much farnesol as the wild-type, was 4 - to 5-fold less pathogenic. Reconstitution of DPP3 restored both farnesol production and pathogenicity. ${ }^{11}$ Taken together, these observations show that farnesol can act as a virulence factor for $C$. albicans. We have subsequently discovered a potential basis for this behavior, in that farnesol interferes with the normal progression of cytokine induction in mice infected with C. albicans. ${ }^{12}$

We are interested in the relationships between quorum sensing and virulence and, in particular, whether it is possible to decouple the two. Specifically, we were interested in the possibility of designing analogs that retain farnesol's ability to block hyphal development but lack farnesol's activity as a virulence factor. In order to explore this problem, we required potent QSMs structurally distinct from farnesol. We now report the discovery of a series of highly potent synthetic quorum-sensing molecules, as well as preliminary investigations of their activity in a mouse model of systemic candidiasis.

\section{Results}

When we initiated these studies, there were no synthetic molecules possessing a significant fraction of farnesol's biological activity as a quorum-sensing molecule. Previously, we had probed farnesol's mode of action with over 40 natural and synthetic farnesol analogs. ${ }^{6}$ Modified structural features included the head group, chain length, presence or absence of the three double bonds, substitution of a backbone carbon by $\mathrm{S}$, $\mathrm{O}, \mathrm{N}$, and Se heteroatoms, presence or absence of a 3-methyl branch, and bulkiness of the hydrophobic tail. Although, more than half the compounds showed measurable quorum-sensing activity (inhibition of hyphal development), the best displayed only $7 \%$ of the activity of $E, E$-farnesol. ${ }^{6}$

\subsection{Oxime leads for new QSMS}

While developing a series of fluorescent farnesol ana$\operatorname{logs},{ }^{13}$ we discovered a pentaene oxime 2 with QSM activity $\left(\mathrm{IC}_{50}=10 \mu \mathrm{M}\right)$ superior to any previously investigated analog (Table 1; see the experimental section for a description of the QSM assay). Based on this discovery, we prepared the oxime of farnesaldehyde (3) and found it was also a potent QSM $\left(\mathrm{IC}_{50}=5 \mu \mathrm{M}\right.$, Table 1$)$. The corresponding $O$ methyl ether, farnesaldehyde methoxyoxime 4, was inactive $\left(\mathrm{IC}_{50}>100 \mu \mathrm{M}\right)$, consistent with the results of earlier studies pointing to a requirement for an acidic head group. ${ }^{6}$ However, oxime 3 was found to exhibit significant toxicity (IP) in healthy mice and this class of molecules was not pursued further.

\subsection{Tetrazole QSMS}

The high quorum-sensing activity of oximes $\mathbf{2}$ and $\mathbf{3}$ led us to explore replacement of the primary alcohol of farnesol with other acidic functional groups (Fig. 1). Our earlier work had found farnesoic acid to be a weakly active QSM $\left(\mathrm{IC}_{50}=36 \mu \mathrm{M}\right) .{ }^{6}$ 5-Substituted-1H-tetrazoles are weak acids $(\mathrm{pK} \sim 5)$ often used as lipophilic isosteres for carboxylic acids, ${ }^{[14]}$ and $[15]$ and therefore we investigated several analogs incorporating a tetrazole in place of $\mathrm{C}_{1}-\mathrm{C}_{3}$ of farnesol.

Analogs 5, 6, and 7 were synthesized via cycloaddition of the appropriate nitrile with $\mathrm{Et}_{3} \mathrm{NHN}_{3}$, generated in situ from $\mathrm{NaN}_{3}$ (Scheme 1). ${ }^{16}$

Analog 5, which incorporates a tetrazole in place of the $\mathrm{C}_{1}-\mathrm{C}_{3}$ region of farnesol, was a potent $\mathrm{QSM}$ with $\mathrm{IC}_{50}=7 \mu \mathrm{M}$ (Table 2). However, in agreement with conclusions from our earlier research, ${ }^{6}$ chain length was clearly important. Tetrazole $\mathbf{6}$, although possessing only one fewer backbone carbon than $\mathbf{5}$, was considerably less active, while commercially available 5methyl-1-tetrazole (not shown) was inactive as a QSM at concentrations up to $3 \mathrm{mM}$. Nonyl tetrazole 7 and commercially

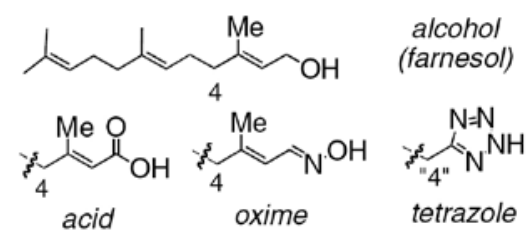

Figure 1. Design concept for analogs.

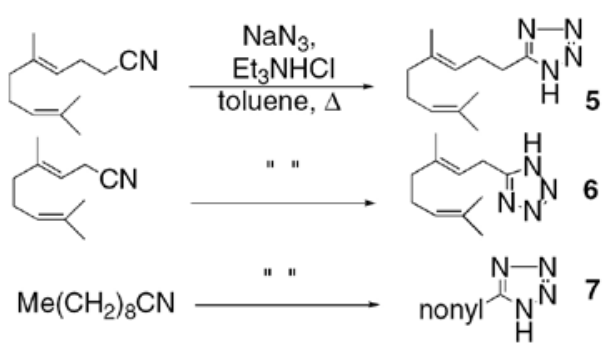

Scheme 1. Synthesis of Tetrazoles. 
available styrenyl tetrazole $\mathbf{8}$ were also highly active; however, 7 was only marginally soluble in water. The strong quorum-sensing activity observed for analogs $\mathbf{5}$ and $\mathbf{8}$ implies a functional equivalency between styrene and 4,8-dimethyl-3,7nonadiene sidechains, suggesting that 3-methyl-5-phenyl-2,4pentadienol or similar structures might represent productive future targets as synthetic QSMs. ${ }^{17}$ Along these lines, it is interesting to note a report indicating that dodecanol, an analog of the 12-carbon homoserine lactone secreted as a QSM by Pseudomonas aeruginosa, is a weak QSM for C. albicans. ${ }^{18}$

\subsection{Other heterocyclic QSMs}

The potency of the tetrazoles as quorum-sensing molecules led us to investigate additional examples of five-membered heterocyclic analogs possessing the same approximate shape, crosssection, lipophilicity, and molecular length (Scheme 2). Our previous studies had found the replacement of a methylene with a sulfur atom (thioether) to be a well-tolerated structural modification, ${ }^{6}$ and we therefore mainly focused on sulfur-linked heterocycles, which are readily available via nucleophilic displacement (Scheme 2) ${ }^{19}$ A similar approach has been employed for synthesis of a thiotriazole from farnesyl chloride. ${ }^{20}$ The substrates tested grafted a series of heterocyclic head groups onto a geranyl (3,7-dimethyl-2,6-octadienyl) tail: thio-1,2,3,4-tetrazole (9), thio-1,2,4-triazole (10), thio1,2,3-triazole (11), and thioimidazole (12). We also investigated a carbon-linked 1,2,3-triazole (13) prepared through a dipolar cycloaddition (Eq. 1). ${ }^{21}$

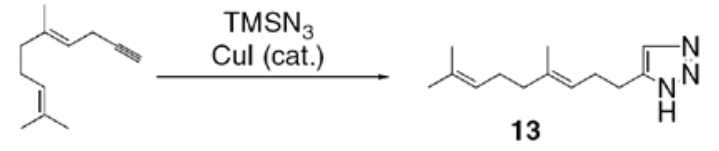

Although thiotetrazole 9 and thioimidazole 12 were only minimally active $\left(\mathrm{IC}_{50}>50 \mu \mathrm{M}\right)$, triazoles $\mathbf{1 0}, \mathbf{1 1}$, and $\mathbf{1 3}$ were potent QSMs (Table 3). It is notable that two of the ana$\operatorname{logs}(\mathbf{1 0}$ and $\mathbf{1 3})$ exhibit QSM activity equal to $E, E$-farnesol, with three other analogs $(\mathbf{5}, 7$, and 11) displaying activities nearly as great. It is important to note that none of the compounds listed in Table 1 and Table 2 had any inhibitory effects on the rate of cell growth, even at the highest concentrations tested $(\geq 100 \mu \mathrm{m})$.

\subsection{Effect of heterocyclic QSMs on candidiasis}

In selecting analogs for mouse assays, we eliminated the nonyl tetrazole 7 due to limited water solubility. Three of the most potent synthetic QSMs $(\mathbf{5}, \mathbf{1 0}$, and 11) were tested next for their potential toxicity to mice following IP injection of $1 \mathrm{ml}$ of a $20 \mathrm{mM}$ solution (ca. $4.4 \mathrm{mg}$ of analog in $0.5 \% \mathrm{v} /$ $\mathrm{v}$ Tween 80 in sterile, nonpyrogenic saline). Attempts to use $0.1 \%$ Triton X-100 in place of Tween 80 were precluded by toxicity. In an initial experiment with 3 mice per group, no toxicity was observed for at least 14 days following injection. In a follow-up experiment with 15 mice per group, also observed for at least 14 days, injection of $\mathbf{1 1}$ caused a slight peri- tonitis and mild hepatomegaly in some mice. Therefore, ana$\operatorname{logs} \mathbf{5}$ and $\mathbf{1 0}$ were chosen for further testing with a standard mouse model of candidiasis, ${ }^{[10]}$ and [11] employing tail vein injection of C. albicans cells and IP injection of the analogs.

Forty-five mice were inoculated with $5 \times 10^{6}$ cells of $C$. albicans A72 through tail vein injection; an additional 45 mice were inoculated with $2 \times 10^{6}$ cells. Each batch of mice was divided into 3 groups of 15 mice each. The chosen doses provide ca. $50 \%$ mortality after 3 days with strain C. albicans A72; ${ }^{10}$ virtually identical results were obtained with each dose. Group 1 was given a control injection (IP, $1 \mathrm{ml}$ of $0.5 \%$ Tween 80 in saline) while groups 2 and 3 were injected with

Table 2. Quorum sensing and toxicity of tetrazoles

\begin{tabular}{lll}
\hline Tetrazole & $\mathrm{IC}_{50}(\mu \mathrm{M})^{\mathrm{a}}$ & Toxicity $^{\mathrm{b}}$ \\
\hline $\mathbf{5}$ & 7 & Non-toxic, virulence factor \\
$\mathbf{6}$ & $>50$ & ND \\
7 & 3 & Non-toxic \\
& & \\
& & \\
8
\end{tabular}

a,b See Table 1 .

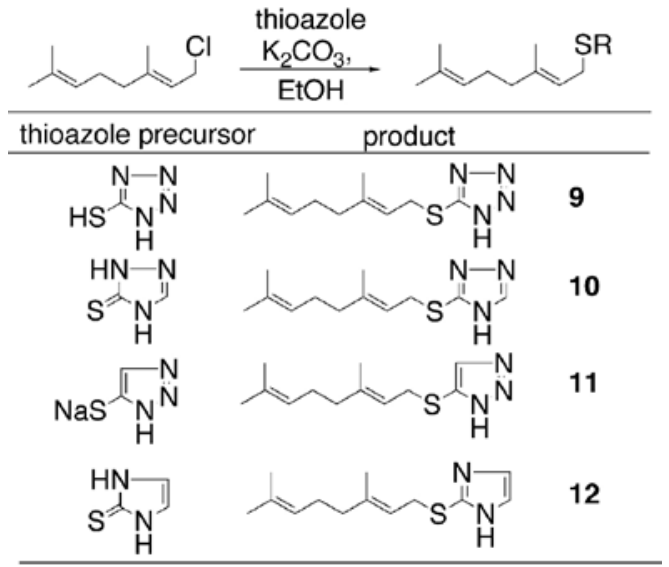

Scheme 2. Additional heterocyclic analogs.

Table 3. Quorum sensing and toxicity in 9-13

\begin{tabular}{|c|c|c|c|}
\hline & Azole $^{\mathrm{c}}$ & $\mathrm{IC}_{50}(\mu \mathrm{M})^{\mathrm{a}}$ & Toxicity $^{\mathrm{b}}$ \\
\hline 9 & & $>50$ & ND \\
\hline 10 & & 1 & $\begin{array}{l}\text { None in } \geqslant 14 d ; \\
\text { not a virulence } \\
\text { factor }\end{array}$ \\
\hline 11 & טות & 3 & Slight \\
\hline 12 & & $>50$ & ND \\
\hline 13 & & $1-2$ & ND \\
\hline
\end{tabular}

\footnotetext{
${ }^{\mathrm{a}, \mathrm{b}}$ See Table $1 ;{ }^{\mathrm{c}} \mathrm{R}=$ geranyl.
} 


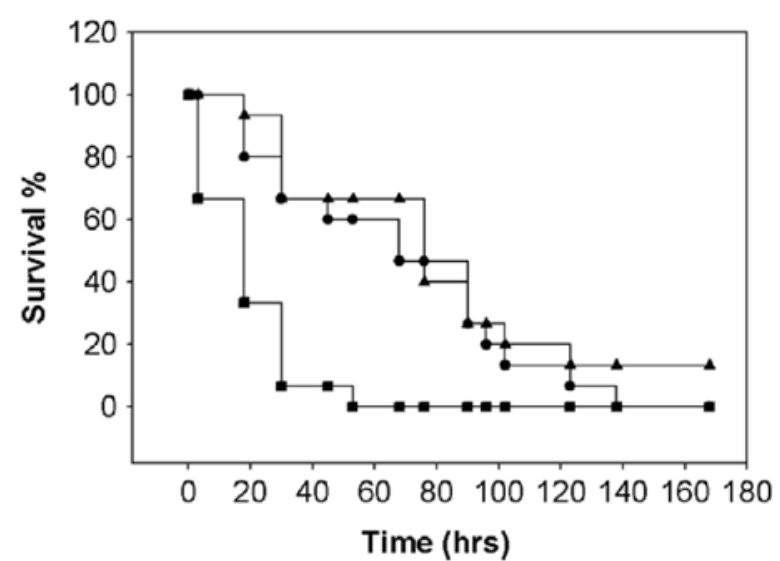

Figure 2. Influence of $\mathbf{5}$ and $\mathbf{1 0}$ on systemic candidiasis. Mouse mortality in the presence and absence of tetrazole $\mathbf{5}$ and triazole $\mathbf{1 0}$ following inoculation with $C$. albicans A72 $\left(5 \times 10^{6}\right.$ cells $)$ and IP injection of $1 \mathrm{ml}$ of: $\bullet$ (saline); $\boldsymbol{\Delta}$ (20 mM thio-1,2,4-triazole 10 in $0.5 \%$ Tween 80$)$; $(20 \mathrm{mM}$ tetrazole $\mathbf{5}$ in $0.5 \%$ Tween 80 ).

analogs $\mathbf{5}$ and 10, respectively. Neither analog protected the mice from candidiasis (Fig. 2). In the case of the thiotriazole 10, mouse lethality closely paralleled that observed for the control Tween 80 injections. In contrast, coadministration of tetrazole 5 enhanced the pathogenicity of $C$. albicans A72 ca. 4- to 5-fold, almost exactly duplicating the effects of farnesol. ${ }^{[10]}$ and $[11]$ The effect is sufficiently pronounced that the entire group of 15 mice treated with 5 died within $60 \mathrm{~h}$ of infection. It is noteworthy that $\mathbf{5}$ and $\mathbf{1 0}$ display opposing effects in vitro (QSM) and in vivo (pathogenicity). Thiotriazole $\mathbf{1 0}$ is ca. 7-fold more potent than $\mathbf{5}$ as a QSM but, unlike the tetrazole, it does not act as a farnesol-mimic in promoting virulence. Thus, the two analogs uncouple the in vitro and in vivo effects of farnesol.

\section{Discussion}

Farnesol is a biologically active, lipid-soluble molecule. We have shown that it blocks the yeast to mycelium transition in C. albicans, ${ }^{3}$ acts as a virulence factor in a mouse model of systemic candidiasis, ${ }^{[10]}$ and ${ }^{[11]}$ probably by interfering with the normal progression of cytokine expression in their immune response, ${ }^{12}$ and triggers apoptosis in the fungus Aspergillus nidulans. ${ }^{22}$ Others have shown that farnesol alters circadian rhythms in Neurospora crassa and targets HMG CoA reductase for proteolysis in both Saccharomyces cerevisiae and Chinese hamster ovary cells. ${ }^{[23], ~[24] ~ a n d ~[25] ~ F a r n e s o l ~ h a s ~ a l s o ~}$ been shown to block calcium channels, stimulating cell differentiation, and triggering apoptosis in other mammalian cell lines. ${ }^{26}$ Farnesol-induced apoptosis has also been reported in tobacco cells. ${ }^{27}$ In addition, farnesol has recently been found to be a potent and selective inhibitor of one class of monoamine oxidases (MAO-B). ${ }^{28}$ The family of heterocyclic farnesol analogs described above now provides a tool to discriminate between yeast-hyphal quorum sensing and pathogenicity. In particular, the availability of molecules such as tetrazole $\mathbf{5}$ (a potent quorum-sensing molecule which enhances pathogenicity) and $\mathbf{1 0}$ (a potent quorum-sensing molecule which does not enhance pathogenicity) may provide a potent tool in understanding how farnesol functions as a virulence factor in interactions with cellular macrophages and CD4 $\mathrm{T}$ cells to alter adaptive immunity. ${ }^{12}$ The analogs also provide a means of establishing differences and similarities between farnesol's effect on virulence and its ability to block both hyphal development and biofilm formation. ${ }^{[3]}$ and ${ }^{[29]}$ Along these lines, it is interesting to note that an analog of triazole $\mathbf{1 0}$ bearing five additional carbons has been reported to be a potent activator of protein kinase C. ${ }^{20}$ Of course, the differences in the pathogenicity of $C$. albicans observed in the presence of farnesol, $\mathbf{5}$, and $\mathbf{1 0}$ could also be due to differing pharmacokinetics or their differing influence on mouse cytokine production.

It is also intriguing to consider the basis for the failure of farnesol, tetrazole $\mathbf{5}$, or thiotriazole $\mathbf{1 0}$ to exert any protective role on the course of systemic candidiasis. One possibility is that the conditions of the experiment were not well suited to test the potential of quorum-sensing molecules as fungistatic therapeutics. Mycelia, the invasive form of the fungi capable of penetrating host tissues to enter the bloodstream, are disfavored by the addition of exogenous farnesol or synthetic QSMs. However, the standard experimental protocol calls for injection of $C$. albicans directly into the bloodstream (tail vein), potentially minimizing the influence of any regimen that disfavors the mycelial morphology. Three other clinical models of candidiasis, oral, ${ }^{30}$ vaginal, ${ }^{31}$ and gastrointestinal, ${ }^{32}$ may provide a more relevant test of the potential of a 'single morphology' therapy for control of fungal infections.

\section{Conclusion}

We have discovered a family of synthetic quorum-sensing molecules for $C$. albicans possessing in vitro potency comparable to $E, E$-farnesol, the natural signal. Investigations of several of the analogs in a mouse model reveals no protection against systemic candidiasis, but do demonstrate the ability to decouple quorum sensing and virulence, suggesting this family of farnesol analogs may prove extremely useful in dissecting the basis for farnesol's many biological activities.

\section{Experimental}

\subsection{General procedures}

Tetrahydrofuran (THF) was distilled from sodium/benzophenone. Other solvents were used as received. All reactions were performed under $\mathrm{N}_{2}$ in oven-dried or flame-dried glassware. All new compounds were characterized by ${ }^{1} \mathrm{H},{ }^{13} \mathrm{C}$, IR, and HRMS. NMR spectra were recorded at $400 \mathrm{MHz}\left({ }^{1} \mathrm{H}\right)$ or $100 \mathrm{MHz}\left({ }^{13} \mathrm{C}\right)$ in $\mathrm{CDCl}_{3}$ unless otherwise noted. IR spectra were collected on $\mathrm{NaCl}$ plates. Melting points are uncorrected. Mass spectra were acquired at the Nebraska Center for Mass Spectrometry (Lincoln, NE). TLC analyses were conducted on Analtech $0.25 \mathrm{~mm}$ GHLF plates, with analytes vi- 
sualized by UV, by dipping in $1 \% \mathrm{KMnO}_{4}$ (specific for alkenes), or by charring after exposure to an aqueous solution of ceric sulfate and ammonium molybdate (general indicator). (E)-5-(2-phenylethyenyl)-1 $H$-tetrazole (8) was purchased from Alfa Aesar ("listed as 5-styryl-1 $H$-1,2,3,4-tetrazole") and used without purification. Abbreviations: EA, ethyl acetate; hex; hexane; HOAc, acetic acid; NBA, 3-nitrobenzylalcohol.

\subsection{Assay of quorum sensing}

Assays for quorum sensing, ${ }^{3}$ toxicity to mice, ${ }^{[10]}$ and $[11]$ and mortality have been described; ${ }^{[10]}$ and [11] a brief overview follows: undifferentiated cells are inoculated to a final density of 1-2 $\times 10^{7}$ cells $/ \mathrm{ml}$ into a solution of $N$-acetyl glucosamine ( $2.5 \mathrm{mM}$, buffered to $\mathrm{pH} 7$ ) and incubated for $4 \mathrm{~h}$ while shaking $\left(200 \mathrm{rpm}, 37^{\circ} \mathrm{C}\right)$, after which the relative percentage of cells with germ tube formation (GTF) is determined. Values from triplicate readings are always within $10 \%$ of the mean value. The relative percentage of cells displaying GTF, 95$98 \%$ for cells grown on unsupplemented media, is reduced considerably in the presence of farnesol or related QSMs. ${ }^{5}$

\subsection{Preparation of Substrates}

The preparation of oximes 2 (anti, 2E,4E,6E,8E)-3,7,11-trimethyldodeca-2,4,6,8,10-pentaenal oxime) ${ }^{13}$ and $\mathbf{3}$ (anti, $2 E, 6 E)$-3,7,11-trimethyldodeca-2,6,10-trienal oxime) ${ }^{33}$ has been described.

\subsection{1. anti- and syn-(2E,6E)-3,7,11-Trimethyldodeca-2,6,10- trienal,O-methyl oxime [anti-4 and syn-4]}

Into a pyridine solution $(5 \mathrm{ml})$ of methoxylamine hydrochloride $(0.109 \mathrm{~g}, 1.3 \mathrm{mmol})$ was added $(2 E, 6 E)$-3,7,11-trimethyldodeca-2,6,10-trienal $(0.115 \mathrm{~g}, 0.52 \mathrm{mmol}$; available through oxidation of commercially available farnesol with $\mathrm{MnO}_{2}$ or chromic acid). After $4 \mathrm{~h}$ the reaction mixture was diluted with water $(50 \mathrm{ml})$ and extracted with $30 \% \mathrm{Et}_{2} \mathrm{O} / \mathrm{Hex}$ $(100 \mathrm{ml})$. The organic layer was dried over $\mathrm{Na}_{2} \mathrm{SO}_{4}$ and concentrated under reduced pressure to afford a mixture which was separated by flash chromatography $\left(2 \% \mathrm{Et}_{2} \mathrm{O} / \mathrm{Hex}\right)$ to afford a mixture of anti-4 $(0.080 \mathrm{~g}, 62 \%)$ and syn-4 $(0.045 \mathrm{~g}$, $38 \%)$.

anti-4. $R_{\mathrm{f}}=0.3(5 \% \mathrm{EA} / \mathrm{Hex}) ;{ }^{1} \mathrm{H} \delta 8.01(\mathrm{~d}, 1 \mathrm{H}, J=10.4)$, $5.92(\mathrm{~d}, 1 \mathrm{H}, J=9.6), 5.09(\mathrm{~m}, 2 \mathrm{H}), 3.86(\mathrm{~s}, 3 \mathrm{H}), 2.15(\mathrm{~m}, 4 \mathrm{H})$, 2.05 (m, 2h), 1.97 (m, 2H), 1.82 (d, 3H, $J=1.2), 1.68(\mathrm{~s}, 3 \mathrm{H})$, $1.60(\mathrm{~s}, 6 \mathrm{H}) ;{ }^{13} \mathrm{C} \delta 147.7,147.5,135.8,131.3,124.2,123.2$, $117.8,61.5,40.0,39.6,26.7,26.0,25.7,17.7,17.2,16.0$; IR 2965, 2932, 2855, 1443, 1051; MS (HR FAB, 3-NBA) calcd for $\mathrm{C}_{16} \mathrm{H}_{28} \mathrm{NO}\left(\mathrm{MH}^{+}\right)$: 250.2171; found 250.2160 (4.4 ppm).

syn-4. $R_{\mathrm{f}}=0.2(5 \% \mathrm{EA} / \mathrm{Hex}){ }^{1} \mathrm{H} \delta 7.27(\mathrm{~d}, 1 \mathrm{H}, J=10)$, 6.41 (dd, 1H, $J=10,1.2), 5.09$ (m, 2H), 3.90 (s, 3H), 2.17 (m, $4 \mathrm{H}), 2.06(\mathrm{~m}, 2 \mathrm{H}), 1.98(\mathrm{~m}, 2 \mathrm{H}), 1.87(\mathrm{~d}, 3 \mathrm{H}, J=1.2), 1.69$ $(\mathrm{d}, 3 \mathrm{H}, J=0.8), 1.61(\mathrm{~s}, 6 \mathrm{H}) ;{ }^{13} \mathrm{C} \delta 149.8,144.8,135.9,131.4$, $124.2,123.2,113.3,61.8,40.2,39.7,26.7,26.1,25.7,17.7$, 17.1, 16.0; IR 2964, 2932, 2855, 1639, 1441, 1056; MS (HR FAB, 3-NBA) calcd for $\mathrm{C}_{16} \mathrm{H}_{28} \mathrm{NO}\left(\mathrm{MH}^{+}\right)$: 250.2171; found 250.2166 (1.8 ppm).

\subsection{2. (E)-5,9-Dimethyldeca-4,8-dienenitrile}

This compound was prepared by a variant of a known procedure. ${ }^{34}$ Into a $-78{ }^{\circ} \mathrm{C}$ solution of acetonitrile $(0.52 \mathrm{ml}$, $10 \mathrm{mmol})$ in dry THF $(10 \mathrm{ml})$ was added dropwise $n$-BuLi ( $5 \mathrm{mmol}$, $2.0 \mathrm{ml}$, nominally $2.5 \mathrm{M}$ in hexane), followed by geranyl chloride $(0.37 \mathrm{ml}, 2.0 \mathrm{mmol})$. The reaction was allowed to warm to rt, and, after $30 \mathrm{~min}$, quenched with water. The mixture was extracted with $10 \% \mathrm{EA} / \mathrm{hex}(150 \mathrm{ml})$ and the organic layer was dried over $\mathrm{Na}_{2} \mathrm{SO}_{4}$. The crude residue obtained upon concentration was purified by flash chromatography $(5 \% \mathrm{EA} / \mathrm{Hex})$ to afford $0.28 \mathrm{~g}(79 \%)$ of the nitrile as a colorless oil: $R_{\mathrm{f}}=0.2(5 \% \mathrm{EA} / \mathrm{Hex})$.

\subsection{3. (E)-5-(4,8-Dimethylnona-3,7-dienyl)-1H-tetrazole (5)}

Into a suspension of $\mathrm{NaN}_{3}(0.455 \mathrm{~g}, 7.00 \mathrm{mmol})$ in toluene $(5 \mathrm{ml})$ was added $\mathrm{Et}_{3} \mathrm{NHCl}$ (Fluka, $1.10 \mathrm{~g}, 8.00 \mathrm{mmol}$ ) followed by a solution of $(E)$-5,9-dimethyldeca-4,8-dienenitrile (see above, $2.00 \mathrm{mmol}, 0.354 \mathrm{~g}$ ) in $2 \mathrm{ml}$ of toluene. The reaction mixture was held at reflux for $24 \mathrm{~h}$ and then allowed to cool to rt. The mixture was acidified to $\mathrm{pH} \sim 1$ with $10 \%$ aq $\mathrm{HCl}$ and extracted with $20 \% \mathrm{EA} / \mathrm{Hex}(3 \times 100 \mathrm{ml})$. The combined organic layers were concentrated under reduced pressure and the residue purified by flash chromatography $(\mathrm{Hex} / \mathrm{EA} / \mathrm{AcOH}$ 10:2:1) to furnish $0.41 \mathrm{~g}(93 \%)$ of tetrazole 5 as a colorless oil: $R_{\mathrm{f}}=0.3(5: 1: 1, \mathrm{Hex} / \mathrm{AcOH} / \mathrm{EA}) ;{ }^{1} \mathrm{H} \delta 13.55$ (br s, $\left.1 \mathrm{H}\right), 5.18$ (t, $1 \mathrm{H}, J=6.8), 5.04$ (t, $1 \mathrm{H}, J=6.5), 3.14$ (t, $2 \mathrm{H}, J=7.6), 2.56$ (q, 2H, $J=7.2), 2.03(\mathrm{~m}, 2 \mathrm{H}), 1.97(\mathrm{~m}, 2 \mathrm{H}), 1.66(\mathrm{~s}, 3 \mathrm{H}), 1.66$ (s, 3H), $1.58(\mathrm{~s}, 3 \mathrm{H}), 1.52(\mathrm{~s}, 3 \mathrm{H}) ;{ }^{13} \mathrm{C} \delta 156.5,138.4,132.0$, 124.0, 121.3, 39.5, 26.4, 26.1, 25.6, 23.7, 17.7, 15.9; IR 2917, 2625, 1558, 1441, 1376, 1253; HR-FABMS (3-NBA) calcd for $\mathrm{C}_{12} \mathrm{H}_{21} \mathrm{~N}_{4}\left(\mathrm{MH}^{+}\right)$: 221.1766 ; found: 221.1771 (2.1 ppm).

\subsection{4. (E)-4,8-Dimethylnona-3,7-dienenitrile ${ }^{35}$}

Into a solution of $\mathrm{NaCN}(0.196 \mathrm{~g}, 4.00 \mathrm{mmol})$ in ethanol $(10 \mathrm{ml})$ was added geranyl chloride $(0.37 \mathrm{ml}, 2.0 \mathrm{mmol})$. The reaction mixture was stirred for $2 \mathrm{~h}$, diluted with water, and with 5\% EA/Hex (twice). The separated organic layer was dried over $\mathrm{Na}_{2} \mathrm{SO}_{4}$ and concentrated in vacuo. The residue was purified by column chromatography $(5 \% \mathrm{EA} / \mathrm{Hex})$ to furnish $0.313 \mathrm{~g}(96 \%)$ of the known nitrile: $R_{\mathrm{f}}=0.3(5 \% \mathrm{EA} / \mathrm{Hex})$.

\subsection{5. (E)-5-(3,7-Dimethylocta-2,6-dienyl)-1H-tetrazole (6)}

This compound was prepared from (E)-5-(3,7-dimethylocta-2,6-dienenitrile $(0.31 \mathrm{~g}, 1.9 \mathrm{mmol})$ by a similar approach as for 5 . The product $(0.37 \mathrm{~g}, 95 \%)$ was a colorless crystal $\left(\mathrm{mp}=52-54{ }^{\circ} \mathrm{C}\right.$, uncorrected) used without further purification: $R_{\mathrm{f}}=0.3(5: 1: 1, \mathrm{Hex} / \mathrm{AcOH} / \mathrm{EA}) ;{ }^{1} \mathrm{H} \delta 12.8(\mathrm{br} \mathrm{s}, 1 \mathrm{H}), 5.45$ (dt, $1 \mathrm{H}, J=7.2,1.2), 5.05(\mathrm{~m}, 1 \mathrm{H}), 3.82(\mathrm{~d}, 2 \mathrm{H}, J=7.6), 2.05$ (m, 4H), $1.69(\mathrm{~s}, 3 \mathrm{H}), 1.68(\mathrm{~s}, 3 \mathrm{H}), 1.57(\mathrm{~s}, 3 \mathrm{H}) ;{ }^{13} \mathrm{C} \delta 156.0$, 141.5, 132.2, 123.9, 115.7, 39.3, 26.2, 25.6, 22.5, 17.6, 16.2; IR 3417, 2971, 2916, 2732, 2253; HR-FABMS (3-NBA) calcd for $\mathrm{C}_{11} \mathrm{H}_{19} \mathrm{~N}_{4}\left(\mathrm{MH}^{+}\right)$: 207.1610; found: 207.1612 (1.3 ppm).

\subsubsection{5-Nonyl-1H-tetrazole (7)}

This compound was prepared from decanonitrile $(0.38 \mathrm{ml}$, $2.0 \mathrm{mmol}$ ) by a similar method as employed for synthesis of 
5 and 6. The crude material $(0.359 \mathrm{~g}, 91 \%)$ displayed spectra identical to literature reports ${ }^{36}$ and was used without further purification: $R_{\mathrm{f}}=0.2(5: 1: 1, \mathrm{Hex} / \mathrm{AcOH} / \mathrm{EA})$.

\subsection{7. (E)-5-(3,7-Dimethylocta-2,6-dienylthio)-1H-tetrazole} (9)

Into a solution of 5-mercapto-1H-tetrazole $(0.20 \mathrm{~g}$, $2.0 \mathrm{mmol})$ in ethyl alcohol $(10 \mathrm{ml})$ were added $\mathrm{K}_{2} \mathrm{CO}_{3}(0.55 \mathrm{~g}$, $4.0 \mathrm{mmol})$ and geranyl chloride $(0.19 \mathrm{ml}, 1.0 \mathrm{mmol})$. After $12 \mathrm{~h}$, the reaction mixture was acidified to $\mathrm{pH} 7$ and extracted with $50 \%$ EA/Hex $(3 \times 50 \mathrm{ml})$. The combined organic extracts were dried with $\mathrm{Na}_{2} \mathrm{SO}_{4}$. The residue obtained upon concentration in vacuo was purified by flash chromatography $(5: 1: 1$ $\mathrm{Hex} / \mathrm{AcOH} / \mathrm{EA})$ to furnish $0.213 \mathrm{~g}(89 \%)$ of mercaptotetrazole 9 as a colorless oil: $R_{\mathrm{f}}=0.2(5: 1: 1, \mathrm{Hex} / \mathrm{AcOH} / \mathrm{EA}) ;{ }^{1} \mathrm{H}$ $\delta 13.0$ (br s, 1H), 5.37 (t, $1 \mathrm{H}, J=7.6), 5.03$ (t, $1 \mathrm{H}, J=6.4)$, $3.97(\mathrm{~d}, 2 \mathrm{H}, J=8), 2.03(\mathrm{~m}, 4 \mathrm{H}), 1.68(\mathrm{~s}, 3 \mathrm{H}), 1.66(\mathrm{~s}, 3 \mathrm{H})$, $1.56(\mathrm{~s}, 3 \mathrm{H}) ;{ }^{13} \mathrm{C} \delta 155.1,143.4,132.1,123.5,116.8,39.4$, 31.4, 26.2, 26.6, 17.7, 16.2; IR 3055, 2917, 2727, 2560, 1504, 1447, 1038; HR-FABMS (3-NBA) calcd for $\mathrm{C}_{11} \mathrm{H}_{19} \mathrm{~N}_{4}\left(\mathrm{MH}^{+}\right)$: 239.1330; found 239.1336 (2.2 ppm).

\subsection{8. (E)-3-(3,7-Dimethylocta-2,6-dienylthio)-1H-1,2,4-tri- azole (10)}

Into a solution of $1 H$-1,2,4-triazole-3-thiol $(0.152 \mathrm{~g}$, $1.50 \mathrm{mmol})$ in ethyl alcohol $(10 \mathrm{ml})$ were added $\mathrm{K}_{2} \mathrm{CO}_{3}$ $(0.276 \mathrm{~g}, 2.00 \mathrm{mmol})$ and geranyl chloride $(0.19 \mathrm{ml}$, $1.0 \mathrm{mmol}$ ). After $12 \mathrm{~h}$, the reaction mixture was worked up as for 9 and the residue purified by flash chromatography (40\% $\mathrm{EA} / \mathrm{Hex})$ to furnish $0.235 \mathrm{~g}(99 \%)$ of thiotriazole 10: $R_{\mathrm{f}}=0.3$ (50\% EA/Hex); ${ }^{1} \mathrm{H} \delta 13.70$ (br s, $\left.1 \mathrm{H}\right), 8.18$ (s, 1H), 5.33 (dt, $1 \mathrm{H}, J=1.2,2), 5.02(\mathrm{~m}, 1 \mathrm{H}), 3.80(\mathrm{~d}, 2 \mathrm{H}, J=8), 2.00(\mathrm{~m}, 4 \mathrm{H})$, $1.64(\mathrm{~s}, 3 \mathrm{H}), 1.56(\mathrm{~s}, 3 \mathrm{H}) ;{ }^{13} \mathrm{C} \delta 156.4,147.7,141.5,131.8$, 131.8, 123.6, 118.1, 39.4, 31.2, 26.2, 25.6, 17.6, 16.0; IR 3111, 2924, 1449, 1276, 910, 734; MS (HR-FABMS, 3-NBA) calcd for $\mathrm{C}_{12} \mathrm{H}_{20} \mathrm{~N}_{3} \mathrm{~S},\left(\mathrm{MH}^{+}\right)$: 238.1378; found: 238.1383 (2.3 ppm).

\subsection{9. (E)-4-(3,7-Dimethylocta-2,6-dienylthio)-1H-1,2,3-tri- azole (11)}

Into a $0{ }^{\circ} \mathrm{C}$ solution of the sodium salt of 4-mercapto-1H1,2,3-triazole $(0.262 \mathrm{~g}, 2.2 \mathrm{mmol})$ in ethanol $(10 \mathrm{ml})$ was added geranyl chloride $(0.19 \mathrm{ml}, 1.0 \mathrm{mmol})$. The reaction mixture was stirred for $2 \mathrm{~h}$ and then allowed to warm to RT over the course of $1 \mathrm{~h}$. The reaction mixture was diluted with water and the mixture extracted with $20 \%$ EA/Hex $(3 \times 50 \mathrm{ml})$. The combined organic extracts were dried with $\mathrm{Na}_{2} \mathrm{SO}_{4}$ and concentrated, with the residue purified by flash chromatography $(20 \% \mathrm{EA} / \mathrm{Hex})$ to furnish $0.218 \mathrm{~g}(92 \%)$ of thiotriazole 11. $R_{\mathrm{f}}=0.2(20 \% \mathrm{EA} / \mathrm{Hex}) ;{ }^{1} \mathrm{H} \delta 14.23$ (br s, $\left.1 \mathrm{H}\right), 7.72(\mathrm{~s}$, $1 \mathrm{H}), 5.28$ (d of t, $1 \mathrm{H}, J=1.2,8), 5.02(\mathrm{~m}, 1 \mathrm{H}), 3.54(\mathrm{~d}, 2 \mathrm{H}$, $J=7.6), 1.97(\mathrm{~m}, 4 \mathrm{H}), 1.64(\mathrm{~d}, 3 \mathrm{H}, J=0.8), 1.55$ (s, 3H), 1.47 $(\mathrm{s}, 3 \mathrm{H}) ;{ }^{13} \mathrm{C} \delta 140.7,139.3,133.5,131.6,123.7,118.8,39.3$, 33.0, 26.2, 25.5, 17.6, 15.7; IR 3130, 2916, 1661, 1448, 1228, 1109, 839; HR-FABMS (3-NBA) calcd for $\mathrm{C}_{12} \mathrm{H}_{20} \mathrm{~N}_{3} \mathrm{~S}, \mathrm{MH}^{+}$: 238.1378; found: 238.1369 (3.8 ppm).

\subsubsection{0. (E)-2-(3,7-Dimethylocta-2,6-dienylthio)-1H-imidaz- ole (12)}

This compound was prepared from 2-mercaptoimidazole $(0.12 \mathrm{~g}, 1.2 \mathrm{mmol})$ and geranyl chloride $(0.19 \mathrm{ml}, 1.0 \mathrm{mmol})$ in $96 \%$ yield $(0.227 \mathrm{~g})$ by a similar procedure as for 9 . The crude product was pure by NMR and was utilized without further purification: $R_{\mathrm{f}}=0.4(50 \% \mathrm{EA} / \mathrm{Hex}) ;{ }^{1} \mathrm{H} \delta 12.06(\mathrm{br} \mathrm{s}$, $1 \mathrm{H}), 7.17(\mathrm{~s}, 1 \mathrm{H}), 5.29(\mathrm{dt}, 1 \mathrm{H}, J=1.2,7.6), 5.03(\mathrm{~m}, 1 \mathrm{H})$, $3.62(\mathrm{~d}, 2 \mathrm{H}, J=8), 2.05-1.92(\mathrm{~m}, 4 \mathrm{H}), 1.65(\mathrm{~s}, 3 \mathrm{H}), 1.56(\mathrm{~s}$, $3 \mathrm{H}), 1.46(\mathrm{~s}, 3 \mathrm{H}) ;{ }^{13} \mathrm{C} \delta 140.5,139.6,131.6,123.9,123.8$, 119.0, 39.4, 33.4, 26.2, 25.6, 17.6, 15.6; IR 3094, 2916, 2637, 1447, 1328, 1098; HR-FABMS (3-NBA) calcd for $\mathrm{C}_{13} \mathrm{H}_{20} \mathrm{~N}_{2} \mathrm{~S}$ $\left(\mathrm{MH}^{+}\right)$: 237.1313; found 237.1310 (1.1 ppm).

\subsubsection{1. (E)-4-(4,8-Dimethylnona-3,7-dienyl)-1H-1,2,3-tri- azole (13)}

Into a solution of $(E)-6,10$-dimethylundeca-5,9-dien-1yne $^{37}(0.176 \mathrm{~g}, 1.00 \mathrm{mmol})$ in $9: 1 \mathrm{DMF} / \mathrm{MeOH}(10 \mathrm{ml})$ was added $\mathrm{TMSN}_{3}(1.3 \mathrm{ml}, 10 \mathrm{mmol})$ followed by $\mathrm{CuI}(0.1 \mathrm{~g}$, $0.5 \mathrm{mmol}){ }^{21}$ The mixture was held at $100{ }^{\circ} \mathrm{C}$ for $12 \mathrm{~h}$ and then allowed to cool to $\mathrm{rt}$. The reaction mixture was diluted with water and then extracted with $20 \%$ EA/Hex $(3 \times 70 \mathrm{ml})$. The combined organic layers were dried with $\mathrm{Na}_{2} \mathrm{SO}_{4}$ and concentrated. The residue was purified by flash chromatography $(20 \% \mathrm{EA} / \mathrm{Hex})$ to furnish $0.168 \mathrm{~g}(77 \%)$ of triazole 13 : $R_{\mathrm{f}}=0.2(20 \% \mathrm{EA} / \mathrm{Hex}) ;{ }^{1} \mathrm{H}\left(\mathrm{CD}_{3} \mathrm{OD}\right) \delta 7.53(\mathrm{~s}, 1 \mathrm{H}), 5.15(\mathrm{dt}$, $1 \mathrm{H}, J=1.2,7.2), 5.05(\mathrm{~m}, 1 \mathrm{H}), 2.76(\mathrm{t}, 2 \mathrm{H}, J=7.6), 2.35(\mathrm{q}$, $2 \mathrm{H}, J=7.2), 2.04(\mathrm{~m}, 2 \mathrm{H}), 1.98(\mathrm{~m}, 2 \mathrm{H}), 1.65$ (s, 3H), 1.57 $(\mathrm{s}, 3 \mathrm{H}), 1.54(\mathrm{~s}, 3 \mathrm{H}) ;{ }^{13} \mathrm{C}\left(\mathrm{CD}_{3} \mathrm{OD}, 100 \mathrm{MHz}\right) \delta 144.2,137.7$, $132.3,128.7,125.4,124.2,40.9,28.8,27.8,26.1,24.2,17.9$, 16.3; IR 3140, 2919, 2856, 1448, 1377, 1108, 983, 838; HRFABMS (3-NBA) calcd for $\mathrm{C}_{13} \mathrm{H}_{21} \mathrm{~N}_{3}\left(\mathrm{MH}^{+}\right)$: 220.1814; found: 220.1811 (1.1 ppm).

\section{Acknowledgments}

This work was supported by the University of Nebraska Tobacco Settlement Biomedical Research Enhancement Fund, the John C. and Nettie V. David Memorial Trust Fund, and the Farnesol and Candida albicans Research Fund, University of Nebraska Foundation. NMR spectra were acquired, in part, on spectrometers purchased with NSF support (MRI 0079750 and CHE 0091975). A portion of this research was conducted in facilities remodeled with support from NIH (RR01654401). We thank Jessica Dussault for assistance with graphics.

\section{References and notes}

1 O. Gudlaugsson, S. Gillespie, K. Lee, J. Vande Berg, J. Hu, S. Messer, L. Herwaldt, M. Pfaller and D. Diekema, Clin. Infect. Dis. 37 (2003), pp. 1172-1177.

2 G.L. Macphail, G.D. Taylor, M. Buchanan-Chell, C. Ross, S. Wilson and A. Kureishi, Mycoses 45 (2002), pp. 141-145.

3 J.M. Hornby, E.C. Jensen, A.D. Lisec, J.J. Tasto, B. Jahnke, R. Shoemaker, P. Dussault and K.W. Nickerson, Appl. Environ. Microbiol. 67 (2001), pp. 2982-2992. 
4 K.W. Nickerson, A.L. Atkin and J.M. Hornby, Appl. Environ. Microbiol. 72 (2006), pp. 3805-3813.

5 D.D. Mosel, R. Dumitru, J.M. Hornby, A.L. Atkin and K.W. Nickerson, Appl. Environ. Microbiol. 71 (2005), pp. 4938-4940.

6 R. Shchepin, J.M. Hornby, E. Burger, T. Niessen, P. Dussault and K.W. Nickerson, Chem. Biol. 10 (2003), pp. 743-750.

7 W.C. Fuqua, S.C. Winans and E.P. Greenberg, J. Bacteriol. 176 (1994), pp. 269-275.

8 S.P. Saville, A.L. Lazzell, C. Monteagudo and J.L. Lopez-Ribot, Eukaryot. Cell 2 (2003), pp. 1053-1060.

9 J.M. Hornby and K.W. Nickerson, Antimicrob. Agents Chemother. 48 (2004), pp. 2305-2307.

10 D.H. Navarathna, J.M. Hornby, N. Hoerrmann, A.M. Parkhurst, G.E. Duhamel and K.W. Nickerson, J. Antimicrob. Chemother. 56 (2005), pp. 1156-1159.

11 D.H. Navarathna, J.M. Hornby, N. Krishnan, A. Parkhurst, G.E. Duhamel and K.W. Nickerson, Infect. Immun. 75 (2007), pp. 1609-1618.

12 D.H. Navarathna, K.W. Nickerson, G.E. Duhamel, T.R. Jerrels and T.M. Petro, Infect. Immun. 75 (2007), pp. 4006-4011.

13 R. Shchepin, R. Dumitru, K.W. Nickerson, M. Lund and P.H. Dussault, Chem. Biol. 12 (2005), pp. 639-641.

14 R.J. Herr, Bioorg. Med. Chem. 10 (2002), pp. 3379-3393.

15 C.W. Thornber, Chem. Soc. Rev. 8 (1979), pp. 563-580.

16 S. Fürmeier and J.O. Metzger, Eur. J. Org. Chem. (2003), pp. 885-893.

17 We thank a reviewer for this suggestion.

18 D.A. Hogan, A. Vik and R. Kolter, Mol. Microbiol. 54 (2004), pp. 1212-1223.

19 M. Kume, T. Kubota, Y. Kimura, H. Nakashimizu and K. Motokawa, J. Antibiot. 46 (1993), pp. 316-330.

20 B.A. Gilbert, Y.-H. Lim, J. Ding, J.A. Badwey and R.R. Rando, Biochemistry 34 (1995), pp. 3916-3920.

21 T. Jin, S. Kamijo and Y. Yamamoto, Eur. J. Org. Chem. (2004), pp. 3789-3791.

22 C.P. Semighini, J.M. Hornby, R. Dumitru, K.W. Nickerson and S.D. Harris, Mol. Microbiol. 59 (2006), pp. 753-764.
23 T. Granshaw, M. Tsukamoto and S. Brody, J. Biol. Rhythms 18 (2003), pp. 287-296.

24 A.G. Shearer and R.Y. Hampton, EMBO J. 24 (2005), pp. 149-159.

25 T.E. Meigs and R.D. Simoni, Arch. Biochem. Biophys. 345 (1997), pp. 1-9.

26 P.A. Edwards and J. Ericsson, Ann. Rev. Biochem. 68 (1999), pp. 157-185.

27 A. Hemmerlin and T.J. Bach, Plant Physiol. 123 (2000), pp. 1257-1268.

28 (a)C. Binda, F. Hubálek, M. Li, N. Castagnoli, D.E. Edmondson and A. Mattevi, Neurology 67 (Suppl. 2) (2006), pp. S5-S7. (b)A.A. Khalil, B. Davies and N. Castagnoli, Bioorg. Med. Chem. 14 (2006), pp. 3392-3398.

(c)F. Hubálek, C. Binda, A. Khalil, M. Li, A. Mattevi, N. Castagnoli and D.E. Edmondson, J. Biol. Chem. 280 (2005), pp. 15761-15766.

29 G. Ramage, S.P. Saville, B.L. Wickes and J.L. Lopez-Ribot, Appl. Environ. Microbiol. 68 (2002), pp. 5459-5463.

30 S. Elahi, G. Pang, R. Clancy and R.B. Ashman, Infect. Immun. 68 (2000), pp. 5771-5777.

31 G. Cheng, K. Woznaik, M.A. Wallig, P.L. Fidel Jr., S.R. Trupin and L.L. Hoyer, Infect. Immun. 73 (2005), pp. 1656-1663.

32 G. Samonis, E.J. Anaissie, B. Rosenbaum and G.P. Bodey, Infect. Immun. 58 (1990), pp. 1514-1517.

33 G.C. Zheng and H. Kakisawa, Bull. Chem. Soc. Jpn. 62 (1989), pp. 602-604.

34 D.S. Shin, J. Kor. Chem. Soc. 36 (1992), pp. 579-583.

35 (a)K. Mori and Y. Funaki, Tetrahedron 41 (1985), pp. 2369-2377. (b)T. Takahashi, S. Tomida and T. Doi, Synlett (1999), pp. 644-646.

36 F. Kiuchi, N. Miyashita, Y. Tsuda, K. Kondo and H. Yoshimura, Chem. Pharm. Bull. 35 (1987), pp. 2880-2886.

37 B.H. Lipshutz, G. Bulow, F. Fernandez-Lazaro, S.K. Kim, R. Lowe, P. Mollard and K.L. Stevens, J. Am. Chem. Soc. 121 (1999), pp. 11664-11673. 